CHAPTER 9

\title{
Tackling the Cell Wall of the Grape Berry
}

\author{
L. F. Goulao' ${ }^{1}$ J. C. Fernandes², P. Lopes² and S. Amâncio, ${ }^{2, *}$ \\ ${ }^{I}$ Centro de Ecofisiologia, Bioquímica e Biotecnologia Vegetal, Instituto de Investigação Científica Tropical, IP, \\ Quinta do Marquês, Av. da República 2784-505 Oeiras, Portugal and ${ }^{2}$ Centro de Botânica Aplicada à \\ Agricultura (CBAA)/ DRAT, Instituto Superior de Agronomia, UTL, Tapada da Ajuda 1349-017 Lisboa, \\ Portugal
}

\begin{abstract}
The cell wall (CW) is the dynamic border of plant cells. In grape berries, the CW decisively accounts for the difference between the pulp and skin cells, with direct consequences on the grape characteristics, wine quality and wine-making methods. The softening of mature berries results from the depolymerisation and solubilisation of $\mathrm{CW}$ polymers. Modifications of grape pulp and skin CW provide the flexibility for cell expansion during fruit growth and to modulate the final texture. Wine making and berry processing methods are directly related with the absence, in white wines, or the presence, in red wines, of skin $\mathrm{CW}$ in the fermenting must. Anthocyanin extraction depends directly on skin yielding of the pigment upon $\mathrm{CW}$ degradation. During fruit growth and ripening, the cooperative action between different enzyme families is capital in CW metabolism. The sequencing and public availability of the Vitis genome allowed us to focus on individual pathways, to profile the expression pattern of isoforms associated with each tissue, developmental phase or stress response, anticipating the effects on berry (and wine) production and quality. Retrieving the sequences of genomic coding regions and the predicted enzymes that act on the Vitis, CW allows us for the first time to tackle the grape berry Cell Wallome.
\end{abstract}

Keywords: Cell wall enzymes, Cellulose, Glycoproteins, Hemicelluloses, Lignin, Microfibrils, Pectins, Phenolic compounds, Polysaccharides, Primary cell wall, Secondary cell wall, Wallome, Xyloglucans.

\section{INTRODUCTION}

The plant cell wall $(\mathrm{CW})$ is a complex macromolecular structure that surrounds and protects the cell. Functions of the primary wall include plant structural and mechanical support, determination and maintenance of cell shape, resistance to internal turgor pressure of the cell, control over growth at a precise rate and direction, regulation of diffusion through the apoplast, and protection against pathogens, dehydration and environmental factors [1]. Thus, the CW is an important source of biologically active signalling molecules, regulating cell-to-cell interactions and also a carbohydrate storage reserve. Remodelling of the fruit $\mathrm{CW}$ is mandatory to provide the flexibility required for cell expansion during fruit growth and to modulate final texture attributes which, together with flavour and aroma, render the fruit attractive to a variety of seed-dispersing organisms [2]. Therefore modifications of the wall polymers must be fine-tuned to regulate the $\mathrm{CW}$ dynamics needed to accommodate growth and ripening.

The nutraceutical effect of wine, grape and grape derivatives is commonly associated with the antioxidant properties of the phenolic species they contain $[3,4]$. The colour, astringency and antioxidant properties of wines, in particular of red wines, can be assigned to phenolic acids, to simple flavonoids like anthocyanins or to condensed flavonoids as proanthocyanidins (PA) and tannins [3,5]. These phenolic compounds can be solubilised into the vacuole or linked to the $\mathrm{CW}$ polysaccharides. Hence, the $\mathrm{CW}$ of grape berry skin cells is also of main relevance to wine- making and other grapevine processing methods, since it forms a hydrophobic barrier to the diffusion of phenols, holding the main control of extractability [6].

The release of the Vitis genome [7, 8] hastens omics-related research. Profiling the expression patterns of genes associated with Vitis berry $\mathrm{CW}$ during growth, development and in response to abiotic and biotic stresses provides the understanding of $\mathrm{CW}$ impact on grape and wine production and quality.

*Address correspondence to S. Amâncio: Centro de Botânica Aplicada à Agricultura (CBAA)/ DRAT, Instituto Superior de Agronomia, UTL, Tapada da Ajuda 1349-017 Lisboa, Portugal; E-mial: author: samport@isa.utl.pt 


\section{THE PLANT CELL WALL STRUCTURE AND COMPOSITION}

\section{Primary Cell Wall}

The primary $\mathrm{CW}$ of dicotyledonous and non-commelinoid monocot species (Type-I cell walls, according to Carpita and Gibeaut [9]) is composed of approximately 90\% polysaccharides [10] from three major classes that form its structural elements: cellulose, matrix cross-linking glycans (henceforth referred to as hemicelluloses) and pectic polysaccharides, which, in fruits, represent about $35 \%, 15 \%$ and $40 \%$ of the CW mass, respectively [1]. Structural glycoproteins, phenolic esters, minerals, and enzymes are also present, directing modifications on its physical and chemical properties.

Cellulose is a linear polysaccharide consisting of long unbranched $\beta-1,4$-linked cellobiose chains. It forms a crystalline or semi-crystalline microfiber phase, via extensive hydrogen bonding between individual strands (microfibrils) that, winded together, provide most of the tensile strength to the plant cell matrix and forms the framework around which the other components are positioned. Cellulose microfibrils are embedded in a matrix phase consisting of hemicelluloses and pectic polysaccharides.

Hemicelluloses are cross-linking glycans that can interact non-covalently trough hydrogen-bonds to cellulose microfibrils, having the capacity to coat and tether them together to form an extensive framework. Hemicelluloses consist of polysaccharides with a backbone of 1,4- linking $\beta$-D-pyranosyl residues in which $O-4$ is in the equatorial orientation. They differ from cellulose due to its substitution with other sugars, which results in considerable variation in their composition and structure.

Xyloglucans (XGs) are the predominant hemicelluloses in the dicot primary CW, representing 15-25\% [9]. Non-Solanaceae Type-I CW XGs are composed of repeating heptasaccharide units to which variable amounts of sugar residues are added during synthesis up to about $75 \%$ of the $\beta-1,4-\mathrm{D}-\mathrm{Glc} p$ backbone residues [11], resulting in a family with large heterogeneity. Short side chains holding xylose-containing mono- (xylose), di(xylose-galactose) or tri- (xylose-galactose-fucose) saccharides are linked by $\alpha-1,6$ bonds at regular sites to the $O-6$ position of the glucose units of the linear backbone of XG. XGs occur at distinct locations in the wall, either binding tightly to portions of exposed faces of glucan chains in the cellulose microfibrils, or spanning the distance between adjacent microfibrils to lock them into place. Recently, XGs and xylans have been localised to cell junctions in ripening fruits, suggesting a role of hemicelluloses in cell adhesion [12], which was previously attributed to pectic homogalacturonans (see below).

Other hemicelluloses include mannans (a $\beta$-1,4-mannose backbone, with or without galactose linked by an $\alpha-1,6$ bond), including glucomannans, galactomannans and galactoglucomannans, and xylans (a backbone of $\beta$-1,4-linked xylosyl residues, substituted by $\beta$-linked $4-O$-methylglucuronic acid and by acetyl esters on $\mathrm{C} 2$, and $\alpha$-linked arabinose on $\mathrm{C} 2$ or $\mathrm{C} 3$ ) of some xylosyl residues, forming arabinoxylans, glucuronoxylans and glucuronoarabinoxylans.

Pectins are embedded within the cellulose/hemicellulose network, forming hydrophilic gels that impose mechanical features to the wall, such as regulation of the hydration status and ion transport, definition of the porosity and stiffness which, in this way, determines the water holding capacity, controls the permeability of the wall for enzymes and provides additional strength to the matrix. Molar mass, neutral sugar content, proportions of smooth and hairy regions, ferulic acid substitution, amounts of methoxyl and acetyl esters and distribution of ester groups on the polymer characteristically define its fine structure which, in turn, determines functional properties of micro-domains, such as surface charge, $\mathrm{pH}$ and ion balance and establishes the biological roles within the CW. Pectins are complex, structurally heterogeneous acidic polysaccharides composed of a range of 1,4-linked $\alpha$-D-galactosyluronic acid (GalpA) residuecontaining linear chains, assembled with a range of modifications and substitutions with variable degrees of ramifications by single sugars or complex side chains [13]. Structural classes of pectins include homogalacturonan (HG), rhamnogalacturonan-I (RG-I), rhamnogalacturonan-II (RG-II) and, at a lower extent, arabinan, arabinogalactan-I (AG-I) and arabinogalactan-II (AG-II), as well as substituted galacturonans like apiogalacturonan (AGA) and xylogalacturonan (XGA). 
HGs are polymers formed by $\alpha-1,4-$ linked linear chains of more than 72-100 GalpA residues [14], and can account for more than $60-65 \%$ of the total plant pectins. The walls of fruits such as tomato and mango have up to $35 \%$ and $52 \%$ of uronic acid, respectively $[15,16]$. HG GalpA residues may be methyl-esterified at the C-6 carboxyl and/or acetylated at the $O-2$ or $O-3$ position. Methyl-esterification is tightly regulated in a developmental and tissue-specific way. Methyl-esterified regions have neutral charge, but the unmethylated Gal $p \mathrm{~A}$ residues are negatively charged and may be ionically cross-linked with $\mathrm{Ca}^{2+}$ to form stable gels with other pectic molecules, when stretches of 10 or more consecutive un-methyl-esterified residues occur. The hypothesised in vivo structure of the HG-calcium complex is referred to as the "egg-box" [17] and describes the close packing of $\mathrm{HG}$ that occurs upon $\mathrm{Ca}^{2+}$-induced gelling in the $\mathrm{CW}$ of plants. Methylesterification neutralises the charge on GalpA residues and thereby abolishes their ability to cross-link calcium ions. The occurrence of micro-domains inside the pectic polysaccharides means the localisation of precise areas with distinct properties as the result, to some extent, of a different, localised demethylation mechanism which may lead to stiffening or loosening of the wall (reviewed by Goulao [18]).

RG-I is the major branched, heterogeneous and hydrated component of the middle lamella and primary CWs. It consists of a backbone holding a variable number of $\alpha$-1,4-linked Gal $p \mathrm{~A}$ and $\alpha-1,2$-linked rhamnose repeats, and three types of neutral sugar side groups attached to the 4-position of approximately $20-80 \%$ of the rhamnose backbone units, depending on the source of the polysaccharide [19]. These sidechains can derive from single or polymeric substitutions and are mainly composed of $\alpha-1,5$-L-arabinans, $\beta$ 1,4-D-galactans and arabinogalactans, where arabinose is usually terminal and galactose links can be connected through C-4, C-3 or C-6. Its abundance is developmentally and differentially regulated [20].

RG-II molecules are stretches of HG backbone approximately 7-9 $\alpha-1,4-\mathrm{D}-\mathrm{Gal} p \mathrm{~A}$ residues long, substituted with clusters of four highly complex and well-defined conserved side chains that contain 12 different types of sugars, in more than 20 different linkages [21]. Its structure consists of self-associated dimers crosslinked by single borate diesters [22, 23] and stabilised by the presence of calcium [24].

The three main pectin domains, HG, RG-I and RG-II, are described as being covalently linked to form the pectic matrix, envisioned as a unique and complex macromolecule [25-27], although the nature of their covalent arrangements is still unclear. A representation of the pectin network was proposed by Vincken et al. [26] and afterwards supported by Coenen et al. [27], in which RG-I supplies the main backbone to which HG, RG-II and the other less abundant pectic domains are covalently cross-linked to form side-chains of the same molecule.

In addition to the polysaccharides, primary $\mathrm{CW}$ contains about $10 \%$ structural proteins, and protein rods act as supporting brackets to the long polysaccharide chains [28]. Five classes of structural apoplastic proteins have been described: extensins, glycine-rich proteins (GRPs), proline-rich proteins (PRPs), arabinogalactan proteins (AGPs), and solanaceous lectins [29]. Extensins are rich in hydroxyproline amino acid residues that may covalently cross-link polysaccharides to form an interlocking framework where the ends of the protein rods are wrapped around the cellulose microfibrils [30]. AGPs are proteoglycans that have been mainly implicated in cell adhesion [31].

\section{Secondary Cell Wall}

When the cell stops dividing and expanding, in some tissues lignin is deposited within the cellulose microfibrils and matrix carbohydrates, establishing chemical bonds with non-cellulosic carbohydrates, forming a thick secondary $\mathrm{CW}$. According to the chemical groups that stabilise polysaccharide-phenol complexes, two types of bonds are identified: hydrogen bonds between the hydroxyl groups of phenols and the oxygen atoms of $\mathrm{CW}$ polysaccharides sugar moieties or hydrophobic interactions with secondary structures of some polysaccharides [3]. Generally, secondary CWs consist of three layers: outer (S1), middle (S2), and inner (S3) $[3,32]$. The formation of secondary walls occurs mainly in xylem vessels, structural fibers, seed pods and seed integument, as in grapevine berry seeds $[33,34]$. The process starts in the middle lamella and the primary wall (initiation of S1 formation). When the polysaccharide matrix of the S2 layer is completed, lignification proceeds through the secondary wall [35], in particular at the final stage of xylem differentiation [36]. Lignin deposition is then developmentally programmed assuring structural 
integrity and waterproof of the CW and enabling the transport of water and solutes through the vascular system, although its biosynthesis can also be induced by biotic and abiotic stress conditions [35, 37].

Lignin, the second most abundant plant organic compound, is a branched heteropolymer of phenylpropanoids synthesised from the polymerisation of the three most abundant $p$-hydroxycinnamyl monolignols, $p$-coumaryl, $p$-coniferyl and $p$-sinapyl alcohols, which, once incorporated into the polymer, are referred to as $p$-hydroxyphenyl $(\mathrm{H})$, guaiacyl $(\mathrm{G})$ and syringil $(\mathrm{S})$ units, respectively $[34,38,39]$. The relative amount of each unit varies between species, tissues and environmental conditions [34]. Dehydrogenated monolignols can form dimers through covalent bonds between the central carbon of the monolignol tail $\beta-\beta$ type [34], or between the $\beta$ carbon and $\mathrm{C}$ atoms of the aromatic ring, e.g. $\beta-O-4$ or $\beta-5$. After a new dehydrogenation of the dimer, another covalent bond can be established by a polymerisation process of one unit at a time. Molecular species other than the canonical monolignols can be integrated in the lignin polymer, which explains the plasticity of the polymerisation process and the variability of the final polymer $[34,36]$. The lignin of angiosperms, as stands for the grapevine, is almost exclusively composed by $\mathrm{G}$ and $\mathrm{S}$ subunits. In poplar, a woody plant, the linear lignin length is between 13 and 20 units [40], but no reports are available for the length of the grapevine lignin chain.

\section{MODELS OF SUPRA-MOLECULAR ARCHITECTURE OF THE PRIMARY CELL WALL}

The CW is represented as a three-dimensional network containing interconnected fluid-filled pores that form pathways for solutes through the walls. Although the complexity of the primary CW supraorganisation and architecture is under continuous debate, a model of supramolecular organisation of the dicot primary CW based on the "tethered network" model $[11,41]$ has been the most consensual in the last years. In this model, XG is proposed to form hydrogen bonds with cellulose microfibrils, acting as a load bearing tether between the microfibrils, which reinforces the $\mathrm{CW}$. Its location both in the inner and outer surfaces of microfibrils allows for the binding of adjacent microfibrils, while preventing hydrogen bonding between cellulose microfibrils, and thus facilitating each microfibril to slide during cell expansion. Yet, only about ca $8 \%$ [42] of the cellulose microfibril surfaces are covered with XGs and not all of the XG is adsorbed to cellulose [42, 43]. Moreover, XGs bind to the surface of cellulose microfibrils making CWXG a composite structure in which cellulose crystallites are embedded in a matrix of XG with a semi-rigid (straightened backbone) conformation, that is, a matrix that is partly ordered rather than amorphous [44].

This XG-cellulose network is considered to be organised independently and embedded in a second network formed by an amorphous pectin matrix, which acts as a cement (reviewed by Cosgrove [45]) where the negatively charged chains of polygalacturonic acid provide the capacity of interacting and binding with positively charged molecules such as polyamines, cations and positive charges of proteins. However, in muro covalent linkages between RG-I-arabinan side chains and cellulose microfibrils [46-51], and anionic complexes derived from covalent linkages between XG and pectins have been reported [52-57]. RG-I was found to be very firmly integrated into the wall $[58,59]$, providing structural links between the two major CW networks, which are expected to have a role in maintaining the structure of the wall. Pectic polymers operating in cell adhesion are possibly tethered into $\mathrm{CW}$ structures by links through $\mathrm{XG}$ located in $\mathrm{CW}$ regions that are important for maintaining cell adhesion [12]. Moreover, as pectic chains are much more flexible than hemicellulose molecules [60], the alignment of the rod-like chain segments with the microfibrillar surface is less likely, and it seems possible that the hydrogen-bonded interface is relatively disordered [61].

Finally, a third network of structural proteins covalently bound to each other and to other cell components is also often considered [62]. Several models have been proposed to explain the CW architecture (reviewed in $[18,45,63])$ but, to date, there seems to be no definitive evidence favouring a given model over the others. Realistic wall models should consider a highly cross-linked wall wherein pectin-pectin, pectin-XG, pectin-cellulose, pectin-phenolics, pectin-protein and XG-cellulose provide a cohesive network.

\section{COMPOSITION OF THE GRAPE BERRY CELL WALL}

The mesocarp of mature grapes follows the typical Type-I CW model, consisting of approximately $90 \%$ by weight of polysaccharides and less than $10 \%$ of a protein fraction rich in arginine and hydroxyproline 
residues. Cellulose and polygalacturonans are the major constituents, each accounting for ca $30-40 \%$ by weight of the polysaccharide component of the walls $[64,65]$. They display, however, significant varietal differences in the relative abundance of the two polysaccharides. While the mesocarp cells of Traminer and Sauvignon Blanc berries have thin CWs, skins, on the other hand, consist of thick-walled epidermal and hypodermal cells [66]. In the exocarp, polysaccharides account for $50 \%$ of the CW material [67], with a glycosyl-residue composition similar to mesocarp walls $[64,68]$. Neutral polysaccharides (cellulose, XG, arabinan, galactan, xylan and mannan) account for 30\%, while acidic pectin substances (of which ca $62 \%$ are methylesterified) account for $20 \%$. The remaining part is composed of $15 \%$ insoluble proanthocyanidins, $<5 \%$ structural proteins [67] and lignin [69].

The pectic fraction is composed of $65 \%$ HG, 10\% RG-I, 2\% RG-II and 23\% neutral side chains [64, 65, 68]. Arabinans and AGI contribute with $4-6 \%$ by weight to the pectic polysaccharides [64]. Noticeably, all berries contain overall high amounts of $\mathrm{HG}$ in comparison with other fruits, and grapes have higher proportions of RG-I compared to other berries [70]. Differences in pectin composition have been observed between the pulp and the skin [65]. Seventy-five percent of the grape berry walls (by weight) originate from the skin, representing $25 \%$ of the total fresh berry weight $[65,71]$. The relative molar distribution (mol \%) of the different polysaccharides in the red wine grape skins was estimated to be 57-62 HG, 6-14 cellulose, 10-11 XG, $7 \mathrm{~mol} \%$, 4.5-5 RGI, 3.5-4 RGII, $3 \mathrm{~mol} \mathrm{\%} \mathrm{AG,} \mathrm{and} \mathrm{0.5-1} \mathrm{mannans} \mathrm{[72].} \mathrm{Also,} \mathrm{the}$ relative abundance of grape skin $\mathrm{CW}$ polymers differs from the pulp. A three-fold higher content of pectic polysaccharide fractions was detected in the skin as compared to flesh tissues [65]. On the other hand, pulp tissues contain a 2-fold more buffer-soluble AGPs and pectins than skins [65, 68].

Hemicellulosic polysaccharides consisting mainly of XGs, comprise approximately $8-12 \%$ of the total wall polysaccharide fraction, both in the pulp and skin $[64,71]$, and the remainder is made up of smaller amounts of mannans, heteroxylans, arabinans, galactans and arabinogalactans $[64,67,71]$. Although grape $\mathrm{XG}$ and XGs isolated from the walls of other dicot plants have similar structures, the amount is lower than the typical XG content of dicot walls [71]. XGs isolated from mesocarp and exocarp CWs of grape berries are composed of eight types of oligosaccharides (XXXG, XLXG, XXLG, XLLG, XXFG, XLFG, XFFG and XXG; see Fry et al. [73] for nomenclature) in similar proportions in the skin and pulp, except for $\mathrm{XXFG}$, which is more abundant in the pulp, and XLFG, which is more abundant in the skin [71].

Concerning secondary compounds, it is assumed that most phenolic compounds are nearly absent from the grape berry flesh, mainly embodied in the skin and seeds. The CW of grape skins includes ca $15 \%$ tannins with an average degree of polymerisation of 28 [3]. Recently, Bidon et al. [69] have reported a PA skin fraction accounting for $54 \%$ of the total extractable PA. Interestingly, a different interaction pattern occurs between flesh and skin CW material and PA, with possible effects on PA extraction and winemaking.

\section{CELL WALL MODIFICATIONS DURING BERRY GROWTH AND RIPENING}

Remodelling of the fruit $\mathrm{CW}$ is mandatory to provide the flexibility required for cell expansion during fruit growth and to modulate final texture attributes which, together with flavour and aroma, render the fruit attractive to a variety of seed-dispersing organisms. In fact, fruit softening during ripening is one of the developmental events whereby most changes occur in the CWs, which explains why most research on fruit CW metabolism has focused primarily on the ripening phase of development.

Grapes develop according to a double sigmoidal curve. The first growth phase (phase I) is due to cell division and subsequently to cell enlargement followed by the lag phase (phase II), which is characterised by the lack of changes in berry weight and volume. The end of this phase coincides with the onset of ripening (veraison, V) and takes place ca 5-8 weeks before maturity. Following veraison, the second growth phase (phase III) occurs with increasing size of the central mesocarp cells, entirely due to cell expansion within the berry. Grape ripening represents the last third of berry development, so grapes soften at the same time as they expand, during this second growth stage. In grapes, after the onset of ripening, in addition to sugar accumulation and water influx, growth results from the synthesis of new CW material [74]. 


\section{Changes in Pulp Cell Walls}

During ripening, the fruit $\mathrm{CW}$ experiences a general increase in pectin solubility, losses of non-glucosyl neutral sugars from pectin side-chains, and loosening of the xyloglucan-cellulose network [75-77]. These events are common to every fruit species and may or not be accompanied by a decrease in the molecular mass of matrix polysaccharides [76,77]. Depolymerisation varies among fruit species and, even within a species, different timing and extent of modifications may occur according to specific genotypes [77].

In grape berries, dissolution of the pulp CW during ripening is observed [78], but apparently no dramatic changes in wall polysaccharide composition seem to occur [74]. Instead, more subtle structural modifications of specific constituent components may contribute to softening.

The total amount of uronic acids (UA) per berry increases rapidly during phase I due to marked increases of newly synthesised highly methyl-esterified HGs [79]. However, this new synthesis of HG occurs more slowly during phases II and III, concomitantly with slower cell enlargement and thinning of walls to accommodate fruit expansion [80], and it is not sufficient to offset thickening and enlargement of walls during these stages [81], as grape pericarp CWs do not thicken appreciably during ripening [66]. However, as a consequence of the increase in cell volume without concomitant wall synthesis, the $\mathrm{CW}$ becomes in fact thinner at the end of maturation [74, 82] both in mesocarp and exocarp [83], which can explain the lower amount of isolated $\mathrm{CW}$ material as ripening progresses, particularly during the last weeks of grape development [82].

The most significant change in the composition and chemical properties of the wall of berry mesocarp cells during the onset of ripening is the decrease in its galactose/galactan content, particularly the $\beta$-1,4-linked GalpA residues [74] corresponding to a significant loss of AG-I from side chains of pectic polysaccharides, from before veraison (BV) to ripe berries [74]. This event has been reported as a crucial step associated with the initiation of softening [82].

Total pectins from Muscat Gordo grapes decline from 58\%, two weeks BV, to $47 \%$, four weeks postveraison (PV) [74]. The type of pectin found in grape berries also changes during ripening, as CW-bound pectins decrease together with an increase in the water-soluble fraction [84]. In fact, at PV, the decrease in wall-bound pectins is accompanied by a two-fold increase in water-soluble polysaccharides [74, 82], disclosing solubilisation mainly of galacturonan as ripening progresses and the grapes soften [74, 84]. A higher solubility of polygalacturonic acid (PGA), AG-II and arabinan is also noticed [74]. However, during veraison, galactose and arabinose content in the water-soluble fraction did not specifically change [85], suggesting that the increase in UA content of the water-soluble fraction is due to degradation or demethylation of pectin, more easily extracted in hot water. It has been suggested that de-esterification increases pectin solubilisation by creating electronic repulsion between negatively-charged molecules that could result in the loosening of weakly attached pectins $[18,86]$. The presence of high molecular mass pectic polysaccharides at BV probably reflects differences in the degree of esterification from initial to later stages. Changes in the degree of pectin methylation seem to be cultivar-specific. While in Gordo an initial decline in the degree of esterification is observed during ripening, in Ugni Blanc, it decreases from $68 \%$ in green stages to less than $20 \%$ as ripening progresses $[74,81]$.

A decrease of the molecular masses of both pectic and hemicellulosic polysaccharides and a reduction in the cellulose and total hemicellulose content are observed at $\mathrm{V}$ and proceed throughout subsequent phases [85]. It should be noted that, according to Nunan et al. [74] at PV cellulose and XG levels decrease on a fresh weight basis but not on a mol\% basis.

In pectin fraction, total amount and the neutral and acidic sugars of the water soluble fraction, temporally increase from $\mathrm{BV}$ to $\mathrm{V}$ stages, decreasing rapidly $\mathrm{PV}[84,85]$. In contrast, neutral sugar of the hemicellulosic fraction decrease from $\mathrm{BV}$ and throughout $\mathrm{V}$ [85]. This discloses a pattern of temporal modifications in grape berry softening in which $\mathrm{CW}$ polysaccharides of the mesocarp are promptly modified from BV to V [85] (Fig. 1). 
Another noteworthy wall modification in grape ripening is an important increase in the content of proteins at PV [74]. From phase II throughout final maturity, the protein content of the mesocarp CW increase by more than 50\% [74]. Amino acid analyses reveal that such increase is largely due to hydroxyproline-rich proteins, including extensins [74, 87] (Fig. 1).

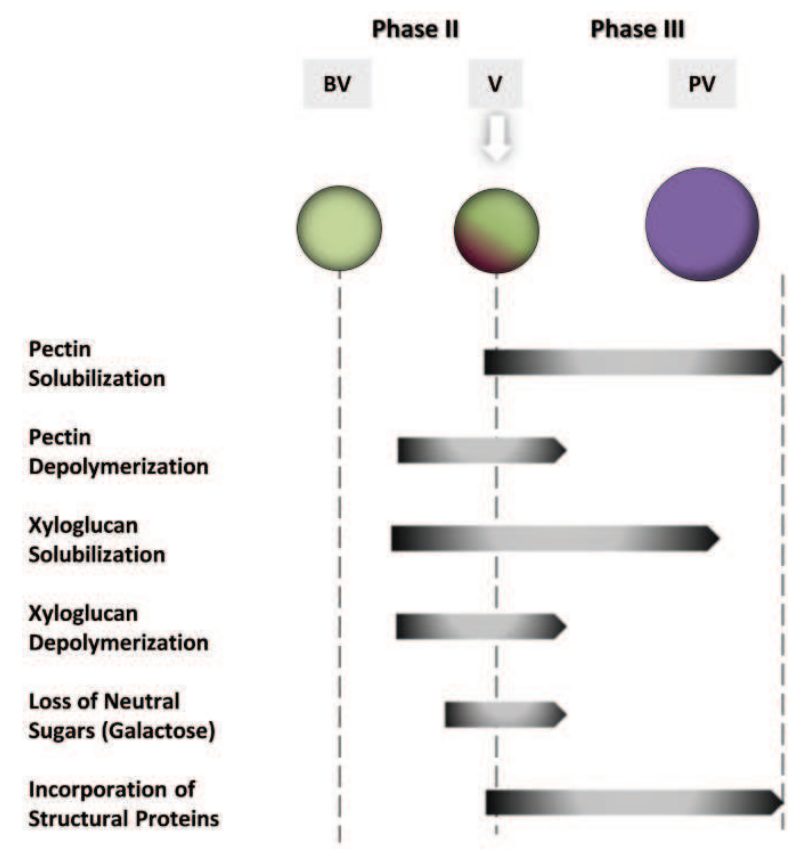

Figure 1: Cell wall modifications during berry growth and ripening. Most significant changes in the composition and chemical properties of the wall of berry cells take place at veraison and post veraison stages, at phases II and III of growth and ripening.

\section{Changes in Skin Cell Walls}

In all development phases the active metabolism of the skin severely influences the final characteristics of the grape berry. Berry size does not change from BV to V, even with the advent of softening, most likely due to the unchanged stiffness of the outer skin [85]. Besides differences in composition (see previous subchapter), there are also differences in the skin CW dynamics when compared to pulp tissues. In fact, the massive dissolution of CW found in the pulp PV [78] was not observed in the skin [66]. However, skin loosens continuously PV. Ultra-structural changes of the loosening skin include wall swelling in epidermis and sub-epidermis cells and degradation of the middle lamella in the hypodermis cells. Additionally, the wall surfaces become "wavy" as the ionic calcium bridge among pectin molecules is broken [88].

Similarly to the pulp, changes in the constituents of the grape skin $\mathrm{CW}$ are well related with the degree of ripening, namely the decrease in the amount of $\mathrm{CW}$ material and galactose [83] in solubilisation of AGP-I, and in the degree of pectin methyl- and acetyl- esterification (most varieties) [89]. Changes in the degree of pectin methylation seems to be cultivar specific since it decreases as ripening progresses in some cultivars like Cabernet Sauvignon, Merlot and Monastrell, while it hardly changes in Syrah [83]. These changes are accompanied by the accumulation of glucose, while other neutral sugars showed no significant variations. However, the amount of skin CW polysaccharides was estimated to correspond to ca $4.2 \mathrm{mg} / \mathrm{berry}$ in Shiraz grapes, remaining constant during ripening [89].

During ripening, a more than two-fold increase in water-soluble fraction occurs both in the pulp and the skin. However, while it stands for 10 to $23 \%$ of the mesocarp CW material [74], it represents a small fraction (3 to $8 \%$ ) in the skin [89]. Even considering that in grapes the pulp to skin weight ratio is about 1:5, a smaller proportion of water-soluble polysaccharides is present in the skin [89], which corresponds to increases of $450-920 \mu \mathrm{g} /$ berry in the pulp of Gordo Muscat compared to a 220-270 $\mu \mathrm{g} /$ berry increase for 
the Shiraz skin tissue $[74,89]$. Likewise, in Grenache Blanc grapes, the water-soluble fraction accounts for $30 \%$ and $13 \%$ of the pulp and skin, respectively [65]. Partial loss of wall structural polysaccharides is compensated by the incorporation of structural proteins and formation of phenolic cross-linkages that happen at the end of the maturation period especially in the walls of epidermis and sub-epidermis cells [88]. Since proteins are confined to the outmost four layers of skin cells, they might contribute to the necessary strength of the tissue to maintain berry integrity, acting as a protective tissue [83, 88]. This aspect may be an important difference in CW modification between the skin and the pulp [88].

Therefore, changes in the skin CWs are continuous but restrained in comparison to other fruits or other grapevine tissues, particularly the small proportion of water-soluble polysaccharides [89], making skin more resistant to solubilisation and maintaining berry integrity.

\section{Modulation of Berry Growth by Mesocarp and Exocarp Cell Wall Modifications}

During phase I, cellular expansion proceeds throughout all tissues, while during the transition between phases II and III only the exocarp cells expand [82], and during phase III (berry growth and ripening) only the expansion of the mesocarp cells occurs. Therefore, grape berry skin controls PV growth by remodelling its CW [88, 90-92]. The loosening of mesocarp CW allows for the accumulation of soluble sugars and takes place prior to the loosening of exocarp CW [91]. Since veraison is observed at the end of the slow growth phase between the first and the second growth stages, little differences occur in berry size during this period, suggesting that rapid structural modifications of $\mathrm{CW}$ polysaccharides verified during veraison without any large change in berry size are due to the unchanged stiffness of the outer skin [85]. This evidence is further supported by differential transcription of genes encoding CW-modifying enzymes (as discussed below). Taken as a whole, changes in $\mathrm{CW}$ components lead to skin loosening and consequently berry enlargement at early PV, and loosening of pulp tissue CW contributes to berry softening [88, 91].

\section{Secondary Cell Wall}

Intense research has focused on the phenylpropanoid metabolism but little attention was given to the characterization of its role in fruit development, particularly in grape berries [38]. In the grape berry and other fleshy fruits, both xylem and phloem vessels deliver water, depending mainly on the developmental stage of the fruit. As a fleshy fruit matures, there is a clear reduction in the proportion of water entering the fruit via the xylem. It was accepted that lignified xylem cells are unable to increase in length during the second stage of berry growth, occurring then a disruption in xylem continuity. However, as under the influence of a hydrostatic gradient, the water movement was recovered, and it is now accepted that the second growth stage is apparently not related to a lack of functionality of xylem vasculature but to an increase in phloem transport [93]. Clues for monolignol polymerisation were reported in Gamay rouge berries as being distributed in the whole fruit but specifically localised to berry xylem vessels at veraison [94].

In mature grape seeds, lignin accounts for $44 \%$ of the CW [95]. In grape seeds, a histochemical study showed that lignin is present in cells of medium integument in increasing amounts as the seed matures. BV lignin is slightly detected in the thin walls of large cells, while at $\mathrm{V}$ and until harvest the staining with specific dyes for lignin was visible in thick walls of increasingly smaller sized cells [33]. The deposition of seed phenolics is associated with berry development and maturation: changes in seed coat colour are related to berry anthocyanins and total skin phenolics, so the colour of the seed coat can be used as an indicator of ripeness [96].

\section{CONNECTION OF THE CELL WALL CHARACTERISTICS TO BERRY TECHNOLOGICAL APPLICATIONS}

\section{Differences between Cultivars}

Contrasting softening behaviours during ripening between fruit genotypes and cultivars from the same species are associated with distinct $\mathrm{CW}$ composition and related enzymatic metabolism [77]. In grapes, the CW composition differs sufficiently between varieties to allow for their discrimination, even with respect to technological differences [83]. The most striking difference between the mesocarp walls of the firm table 
grape cultivar Ohanez and the softer, multipurpose cultivar Muscat Gordo Blanco lies in the relative proportions of cellulose and pectic polysaccharides, and in the hydroxyproline composition of wallassociated structural proteins [64], with Ohanez having significantly higher cellulose and hydroxyproline contents than Muscat Gordo Blanco [64]. In fact, among the most abundant polysaccharides of the grape berry walls, the measured cellulose content is $39 \%$ and $31 \%$ by weight in the Ohanez and Muscat Gordo Blanco cultivars, respectively. Additionally, in Ohanez walls the extensin network is more abundant, which is consistent with its firmer texture [64]. In contrast, galacturonans account for $29 \%$ to $41 \%$ in the same varieties. Therefore, Gordo walls appear to require a larger pectic matrix phase than the firmer Ohanez grapes. Similarly, XG which are probably closely associated with cellulose microfibrils [9], account for 8\% by weight of the walls in Gordo and $12 \%$ in walls from Ohanez [64].

\section{Implications of the Cell Wall in Winemaking}

Different wine processing methods are directly related with the CW. White wines are made by fermenting grape juice, which contains little amounts of skin $\mathrm{CW}$, in contrast to the process of fermenting whole berries in red wines. A first consequence is the amount of RG-II, which is a major polysaccharide component of red wine. One litre of red wine may contain between 100 to $150 \mathrm{mg}$ of RG-II while white wine typically contains 20 to $30 \mathrm{mg}$ of RG-II per litre.

In addition, the $\mathrm{CW}$ of grape berry skin cells is of main relevance to wine making, since it forms a hydrophobic barrier to the diffusion of phenols, holding the main control of extractability [6, 97]. Pinelo et al. [3] propose that phenolic substances, including tannins, can be deposited into the lignin-polysaccharide matrix of lignified secondary $\mathrm{CW}$ or bind to macromolecules, including $\mathrm{CW}$ polysaccharides. It is assumed that most phenolic compounds are nearly absent from the grape berry flesh, mainly embodied in the skin and seeds, and can be released during the wine making process [3]. However, normally there is no reference to lignin, although this phenylpropanoid polymer ornates the secondary walls of xylem vascular bundles in a network that crosses the whole volume of the flesh layer, the main contributor to wine volume [98]. On a per berry basis, tannins accumulate during the first growth period and decline during the second growth stage (phase III) [99]. Then, the degradation of CW polysaccharides is crucial for the yield of phenolic compounds from grape skin cells [69]. The retention of phenols by the CW depends on the composition, structure and molecular weight of the phenol molecule and of CW physical traits [69, 97]. Porosity, structure and chemical composition can influence the aggregation between conformational CW polysaccharides and phenolic substances. The curious concept of phenolic ripeness [100] is associated with anthocyanin content and extractability. Anthocyanin extraction from the grape skin and diffusion into must and wine depends on anthocyanin content but also on the capacity of the berry skin to yield up the pigment as a consequence of $\mathrm{CW}$ degradation. When phenolic ripeness is attained, the pectin-rich middle lamella between cells is degraded, and the CWs are perforated and allow for extraction and diffusion [6].

In berry seeds, tannins have the same constitutive units as the skin tannins but a lower degree of polymerisation [3]. Along with seed growth and development, tannins accumulate when the seed acquires a green colour (phase I); they reach a maximum accompanied by tannin oxidation when seeds show a yellow colour (phase II); and they decrease as the seed dries and matures, taking a brown colour (phase III). The decrease in tannin level is probably related to aggregation of the oxidised forms of the seed coat.

\section{THE VITIS CELL WALLOME}

\section{Vitis Cell Wall Key Enzymes}

The covalent modifications of CW polysaccharides during fruit growth and ripening result largely from the concerted activity of a set of hydrolases and transglycosylases [2, 77, 101]. The cooperative action between members of several different enzyme families, including expansins, endo- $\beta$-1,4-glucanases (EGase), xyloglucan endotransglycosylases/hydrolases (XTH), $\beta$-xylanases $\quad(X y n), \quad$ endomannanases, polygalacturonases (PG) or pectate lyases (PL) are of primary interest in CW metabolism during fruit development. On the other hand, esterases like pectin methylesterases (PME) and pectin acetylesterases (PAE), exo-acting hydrolases and other glycosidases such as $\beta$-galactosidases ( $\beta$-gal), $\alpha$-L- 
arabinofuranosidases (AFase) or xylosidases (Xyl) are also involved through cooperative action with hydrolases in the pectic or hemicellulosic polymer metabolism [101, 102]. Removal of side chains containing neutral sugar may be necessary to expose the polysaccharide's backbone for cleavage, thus facilitating its solubilisation [103] and promoting a decrease in the degree of polymerisation which, in turn, can modify the binding between polymers [104]. Cooperative events can result from the disassembly of the hemicellulosic network proved necessary for modifications in the pectic network due to the physical accessibility of pectolytic enzymes to pectin substrates. The panorama is even more complex because new components are synthesised and integrated into the $\mathrm{CW}$, even during ripening $[105,106]$. Nonetheless, the real contribution of the referred enzymes still remains to be fully elucidated.

As far as the secondary $\mathrm{CW}$ is concerned, after the deamination of phenylalanine by phenylalanine ammonia lyase (PAL) to form cinnamic acid, the lignin synthesis pathway includes hydroxylations of the aromatic ring, methylation of one or two hydroxyl groups and two reductions of the carboxylic to the monolignol alcohol side chain [34]. The crucial enzymes and respective coding genes are cinnamate 4hydroxylase $(\mathrm{C} 4 \mathrm{H})$, 4-coumarate:CoA ligase $(4 \mathrm{CL})$, cynnamoyl CoA reductase (CCR), $\beta$ hydroxycinnamoyl-CoA:quinate/shikimate/p-hydroxy-cinnamoyl transferase (HCT), cinnamyl alcohol dehydrogenase (CAD) and ferulate 5-hydroxylase (F5H). The end products are the monolignols $p$ coumaroyl, $p$-coniferyl and $p$-sinapyl which differ in their methylation degree $[3,34]$. Polymerisation occurs after monolignol dehydrogenation by large families of apoplastic peroxidases and laccases which can vary in specificity according to each type of monolignol $[34,36]$.

\section{The Vitis Cell Wall-Related Genome}

The sequencing and public availability of the Vitis genome [7,8] makes it possible to focus on individual pathways, to profile the expression pattern of isoforms associated with each tissue, developmental phase and response to the different stresses affecting grape berries during their development, and anticipating the effects on wine production and quality. For that reason, retrieving the sequences of coding regions and predicted amino acid primary structure of enzymes known to act on the Vitis $\mathrm{CW}$ is mandatory to support omics-related research. Table 1 provides a list of the number of genes related with primary $\mathrm{CW}$ biosynthesis and modification and with secondary $\mathrm{CW}$ biosynthesis present in the genome of higher plant sequenced species Vitis vinifera, Oryza sativa, Populus trichocarpa and Arabidopsis thaliana.

In silico analysis shows that, in Vitis, most of the primary $\mathrm{CW}$ related gene families present a number of members similar to Arabidopsis, rice and Populus, suggesting the conservation of mechanisms associated with $\mathrm{CW}$ biosynthesis and modification along plant evolution (Table 1). As expected, a higher number of genes involved in the biosynthesis of lignin were retrieved in the woody species Vitis and Populus as compared with Arabidopsis and Oryza, (Table 1) but it is worthy to note that Vitis genome holds more genes than Populus [107].

CesA (Cellulose synthase), XTH (Xyloglucan endotransglucosylase/hydrolase), EGase ( $\beta$-1,4-endoglucanase), PME (Pectin methylesterase), PMEI (Pectin methylesterase/nvertase inhibitor), PAE (Pectin acetylesterase), PG (Polygalacturonase), PL (Pectate lyase), C4H (Cinnamate 4-hydroxylase), HCT (Hydroxycinnamoyl-CoA shikimate/quinate hydroxycinnamoyl transferase), C3H (Coumarate 3-hydroxylase), CCR (Cinnamoyl-CoA reductase), F5H (Ferulate 5-hydroxylase), CAD (cinnamyl alcohol dehydrogenase). The protein sequences were extracted from public databases: Arabidopsis sequences from TAIR (http://www.arabidopsis.org/ index.jsp) and Cell Wall Navigator (http://bioweb.ucr.edu/Cellwall/); rice sequences from orygenesdb (http://orygenesdb.cirad.fr/cgi-bin/gbrowse/odb_japonica/?name=Os_1:1..10000) and Cell Wall Navigator; Populus sequences from JGI (http://genome.jgi-psf.org/Poptrl/poptr1.home.html) and Vitis sequences from Genoscope genomic database 8X (http://www.genoscope.cns.fr/externe/GenomeBrowser/Vitis/). Databases last access September 2010.

Amino acid sequence similarity analyses reveal that Vitis CW-related sequences cluster with orthologs from monocot, dicot and woody model species in most families (Fig. 2A, B). Noticeably, in families such as XTHs some clusters are enriched with Vitis sequences, suggesting specification with respect to evolution or a possible correlation with substrate specificity (Fig. 2C). This aspect may be important to unravel CW dynamics in this species and deserves further investigation. 
Table 1: Number of genes related to primary cell wall biosynthesis and modification and to secondary cell wall biosynthesis retrieved in silico from the higher plant sequenced species Vitis vinifera, Oryza sativa, Populus trichocarpa and Arabidopsis thaliana genomes.

\begin{tabular}{|c|c|c|c|c|}
\hline & Vitis vinifera & Oryza sativa & Populus trichocarpa & Arabidopsis thaliana \\
\hline \multicolumn{5}{|c|}{ Primary Cell Wall } \\
\hline CesA & 11 & 10 & 18 & 10 \\
\hline Expansin & 30 & 56 & 36 & 36 \\
\hline XTH & 33 & 29 & 24 & 33 \\
\hline$\beta$-1,3-glucanase & 43 & 65 & 73 & 49 \\
\hline EGase & 21 & 24 & 31 & 25 \\
\hline PME & 36 & 37 & 84 & 66 \\
\hline PMEI & 11 & 22 & 48 & 33 \\
\hline PAE & 7 & 10 & 11 & 9 \\
\hline PG & 60 & 48 & 45 & 66 \\
\hline PL & 16 & 10 & 27 & 27 \\
\hline \multicolumn{5}{|c|}{ Secondary Cell Wall } \\
\hline $\mathrm{C} 4 \mathrm{H}$ & 5 & 3 & 2 & 1 \\
\hline HCT & 16 & 9 & 11 & 2 \\
\hline $\mathrm{C} 3 \mathrm{H}$ & 3 & 1 & 2 & 1 \\
\hline $\mathrm{CCR}$ & 20 & 12 & 18 & 7 \\
\hline F5H & 3 & 2 & 3 & 2 \\
\hline CAD & 8 & 12 & 12 & 9 \\
\hline
\end{tabular}

\section{The Grape Berry Cell Wall Transcriptome}

One way of tackling the pathways of a given physiological event is to understand the regulation of the transcription of related genes. Initial studies based on "candidate gene" approaches in grapes associated $\beta$ gal, $\alpha$-gal, PME, PL enzyme activity and gene expression with changes in mesocarp CW pectin composition, during berry ripening $[81,82,87,109]$. These events were accompanied by the up-regulation of genes involved in the cellulose:hemicellulose network, such as expansins and XTH, at veraison, coincidently with the depolymerization of XG $[87,109,110]$. In grape berries, the expression of EGase genes seems to be confined to the initial growth stages and was not detected during ripening [87], which contrasts with the large majority of fruit species, except for apple [111,112]. Therefore these genes are pointed out as strong candidates to be involved in the metabolism of the grape berry $\mathrm{CW}$.

In the skin, as stated above, the remodelling of the CW apparently exerts a marked influence on the control of berry growth during phases I and III [92]. The transcription profiles of candidate genes for CW-modifying enzymes support this assumption. A bimodal trend is observed, with high levels of expression coincident with periods of rapid berry growth as well as cellular expansion and low expression levels during growth arrest [92]. Despite major differences in grape cell morphology between the exocarp and mesocarp, most genes for CW metabolic processes follow similar expression profiles in both tissues throughout berry development [92]. However, different patterns in genes for some CW-modifying families, including $\beta-1,3$-endoglucanase, PME, PL, and two genes from the expansin family (EXP3 and EXPL) were observed [92]. The differences are more evident during the rapid growth phase associated with the beginning of phase III, with an up-regulation of $\beta$ 1,3-endoglucanase, EXP3 and EXL gene expression in the exocarp accompanied by a down-regulation in the mesocarp, and a lag in the up-regulated expression of exocarp PL, PME and EXPL during phase II [92]. Noticeably, the up-regulation of exocarp transcripts during transition phases II and III is accompanied by a tissue-specific expansion of both epidermal and hypodermal cells. This exocarp up-regulation followed by the 
down-regulation of $\beta$-1,3-endoglucanase and expansin-like genes discloses patterns of gene expression concurrent with changes in the epidermis and hypodermis $\mathrm{CW}$ thickness, indicating a role in $\mathrm{CW}$ loosening to accommodate expansion of the mesocarp tissues [92]. Moreover, exocarp tissues exhibit a larger increase in transcript level of PME and EGase, in contrast to the increased transcription of EXPL in the mesocarp [92]. It should be emphasised that this research followed a "candidate gene" approach, so the possible involvement of other isoforms and gene families is expected.
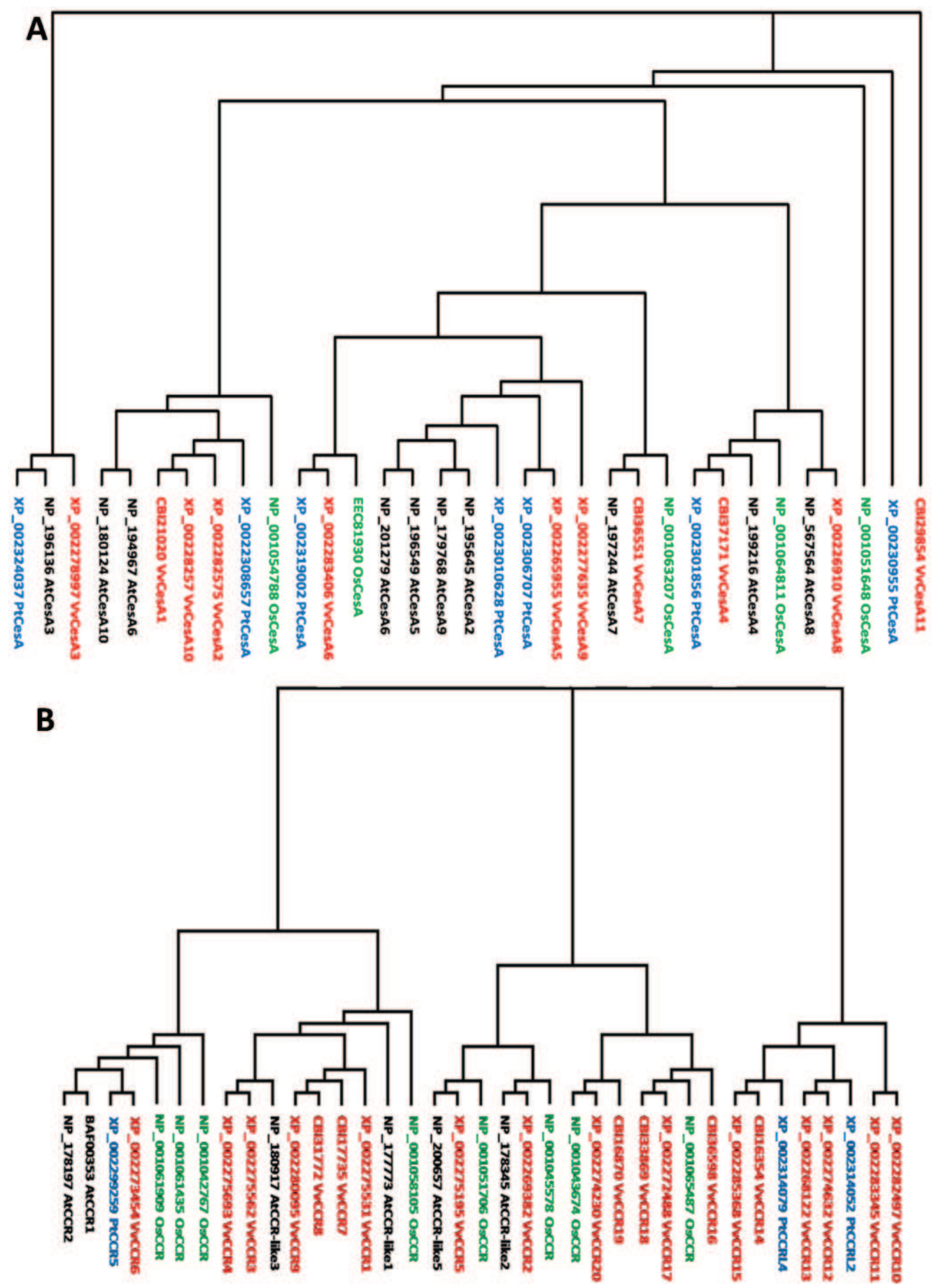
C

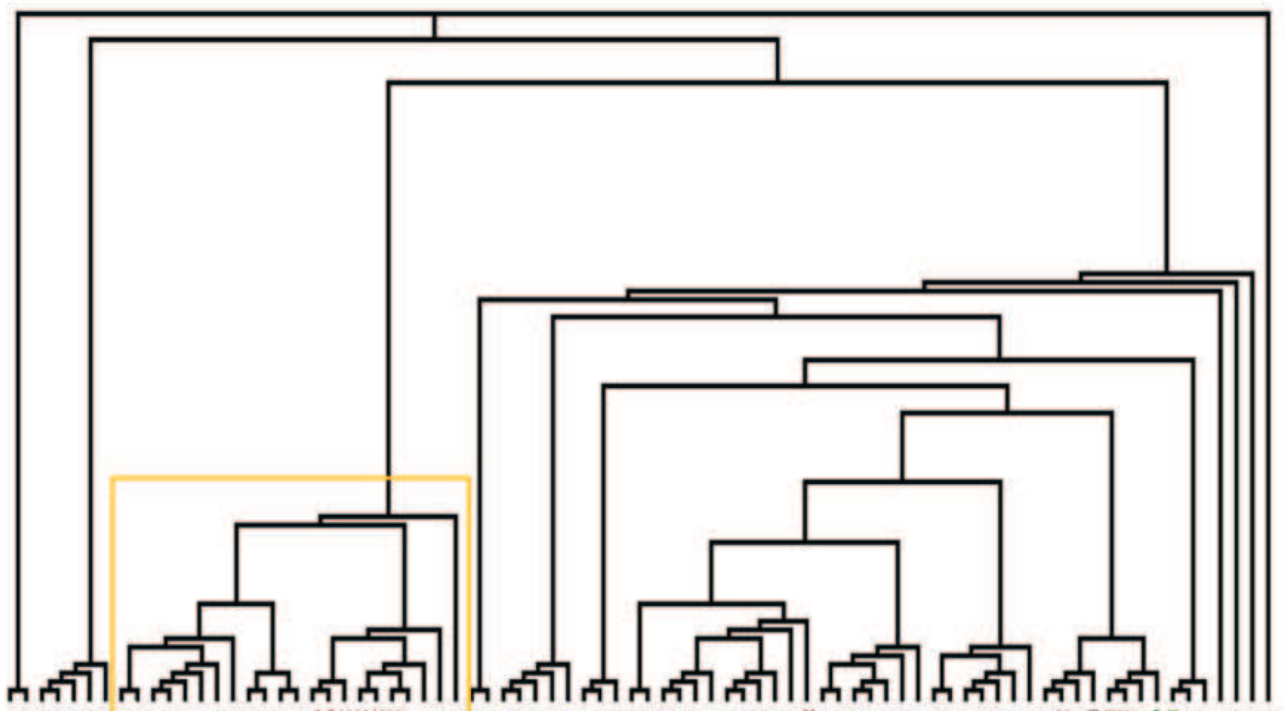

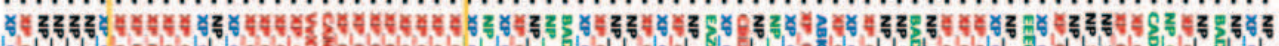
8.6.
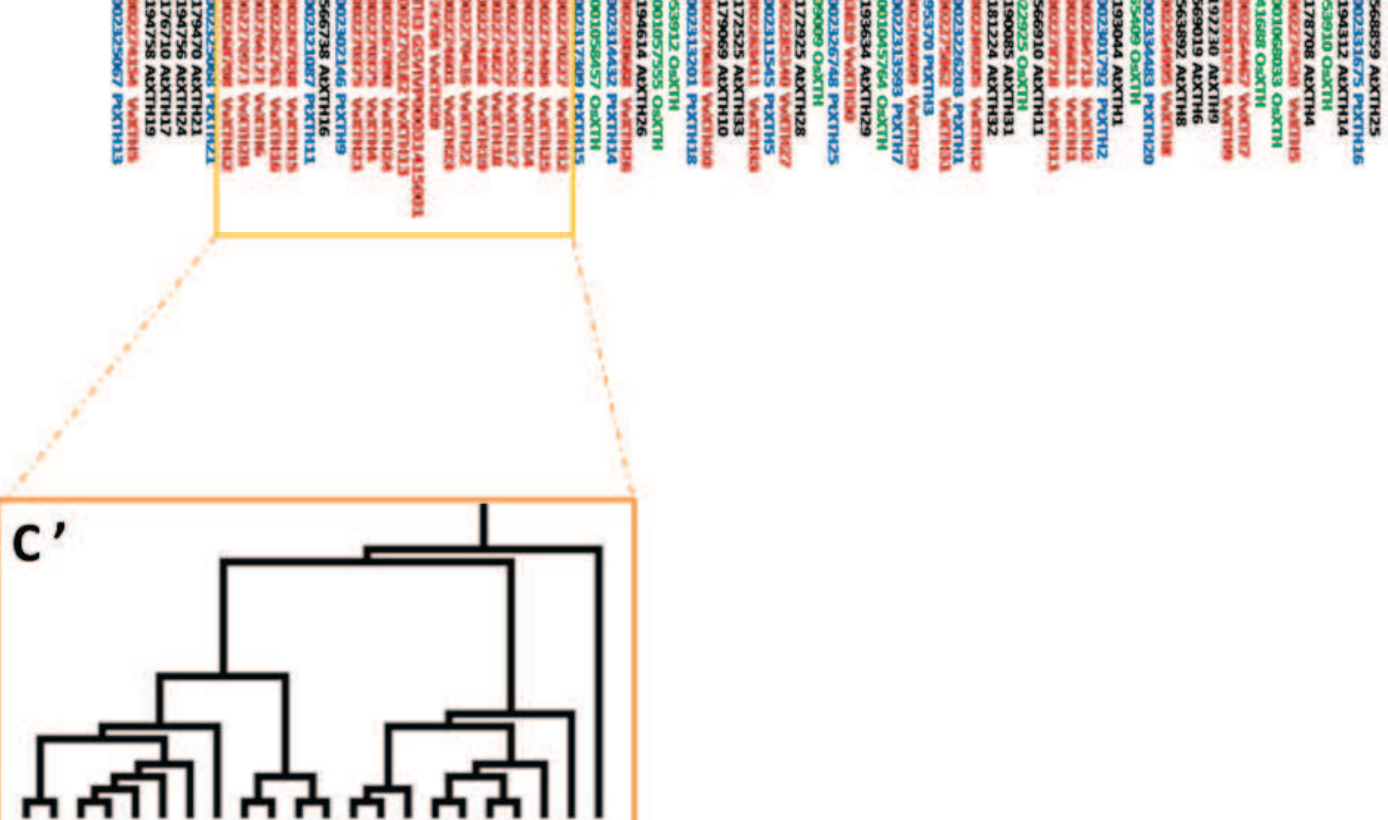

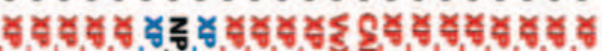

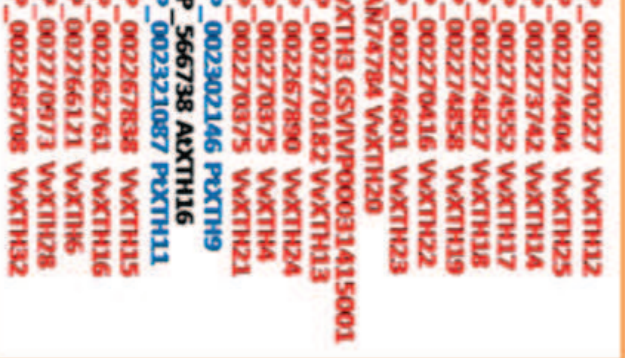

Figure 2: Phylogenetic dendrogram of cellulose synthases (CesA, A), cynnamoyl CoA reductases (CCR, B) and xyloglucan endotransglycosylases/hydrolases (XTH, C; magnification of cluster enriched in Vitis sequences, C'). Dendrograms were generated using ClustalX and TreeView software [108] based on mature protein sequences extracted as in Table $\mathbf{1}$ of all Vitis (red) family members annotated so far and representative members of Arabidopsis (black), Oryza (green) and Populus (blue) protein families. 
With large Expressed Sequence Tags (EST)-based microarrays, new insights about the regulation of CW in Vitis berries was achieved, taking advantage of sequence annotation and high throughput gene expression. The public release of the Vitis genome and the annotation of Vitis genes allowed for the in-depth study of the functional genomics of berry $\mathrm{CW}$, including the genes coding for enzymes associated with $\mathrm{CW}$ biosynthesis, modification during cell growth and fruit ripening as well as the deposition of secondary wall polymers, providing a better picture of the associated pathways. In general, large scale high-throughput transcriptomic microarray data indicate several categories of genes that are significantly differentially expressed during berry development (Table 2). An incidence of genes related to $\mathrm{CW}$ organisation and biogenesis are included in clusters showing overexpression during development, thus disclosing the prevalence of metabolic processes involved in CW synthesis and loosening PV [113].

Table 2: Summary of representative primary cell wall biosynthesis (CesA) and modification gene families (cellulosehemicellulose network: XTH and expansin; pectin network: PG, PME, PMEI) strongly differentially expressed in grape berry tissues during developmental phases or imposed treatments.

\begin{tabular}{|c|c|c|c|c|}
\hline $\begin{array}{l}\text { Gene } \\
\text { family }\end{array}$ & Method & Condition & Tissue & Reference \\
\hline \multirow[t]{3}{*}{ CesA } & Affymetrix Vitis GeneChip ${ }^{\circledR}$ Microarray & Berry development & Deseeded berry & {$[113]$} \\
\hline & & & Whole berry & {$[114]$} \\
\hline & Array-Ready Oligo Set ${ }^{\mathrm{TM}}$ for Vitis & $\mathrm{C} 2 \mathrm{H} 4$ (ethylene) treatment & Whole berry ${ }^{\mathrm{a}}$ & {$[115]$} \\
\hline \multirow[t]{5}{*}{$X T H$} & Affymetrix Vitis GeneChip ${ }^{\circledR}$ Microarray & Berry development & Deseeded berry & {$[113]$} \\
\hline & & & Whole berry & [114] \\
\hline & & Water deficit & Pulp, skin, seed & [116] \\
\hline & Array-Ready Oligo Set ${ }^{\mathrm{TM}}$ for Vitis & $\mathrm{C} 2 \mathrm{H} 4$ (ethylene) treatment & Whole berry ${ }^{a}$ & {$[115]$} \\
\hline & Oligo Array & Berry development & Whole berry & {$[117]$} \\
\hline \multirow[t]{6}{*}{ Expansin } & Affymetrix Vitis GeneChip ${ }^{\circledR}$ Microarray & Berry development & Deseeded berry & [113] \\
\hline & & & Whole berry & [114] \\
\hline & & Water deficit & Pulp, skin, seed & [116] \\
\hline & Array-Ready Oligo Set ${ }^{\mathrm{TM}}$ for Vitis & $\mathrm{C} 2 \mathrm{H} 4$ (ethylene) treatment & Whole berry ${ }^{\text {a }}$ & {$[115]$} \\
\hline & Oligo Array & Berry development & Whole berry & [117] \\
\hline & EST sequencing & Berry development & Whole berry & {$[118,119]$} \\
\hline \multirow[t]{3}{*}{$P G$} & Affymetrix Vitis GeneChip ${ }^{\circledR}$ Microarray & Water deficit & Pulp, skin, seed & {$[116]$} \\
\hline & & ABA treatment & Skin & {$[120]$} \\
\hline & Array-Ready Oligo Set ${ }^{\mathrm{TM}}$ for Vitis & $\mathrm{C} 2 \mathrm{H} 4$ (ethylene) treatment & Whole berry ${ }^{a}$ & {$[115]$} \\
\hline \multirow[t]{6}{*}{$P M E$} & Affymetrix Vitis GeneChip ${ }^{\circledR}$ Microarray & Berry development & Deseeded berry & {$[113]$} \\
\hline & & & Whole berry & {$[114]$} \\
\hline & & Water deficit & Pulp, skin, seed & {$[116]$} \\
\hline & & ABA treatment & Skin & {$[120]$} \\
\hline & Array-Ready Oligo Set ${ }^{\mathrm{TM}}$ for Vitis & $\mathrm{C} 2 \mathrm{H} 4$ (ethylene) treatment & Whole berry ${ }^{a}$ & {$[115]$} \\
\hline & Oligo Array & Berry development & Whole berry & {$[117]$} \\
\hline
\end{tabular}




\begin{tabular}{|l|l|l|l|l|}
\hline & EST sequencing & Berry development & Whole berry & {$[119,121]$} \\
\hline PMEI & Affymetrix Vitis GeneChip® Microarray & Berry development & Deseeded berry & {$[113]$} \\
\hline & & & Whole berry & {$[114]$} \\
\hline & & Water deficit & Pulp, skin, seed & {$[116]$} \\
\hline & EST sequencing & Berry development & Whole berry & {$[118]$} \\
\hline
\end{tabular}

${ }^{\text {a }}$ Gene expression was further investigated individually in the pulp, skin and seed via quantitative real-time RT-PCT.

The previously described involvement of some gene families in berry growth and softening was confirmed with large-scale transcriptomics. Among these are included pectin modifying enzymes (PME, PG and PL) and cellulose-hemicellulosic ones (expansins and XTH). However, in moving from "candidate gene" approaches to "large scale high throughput" transcriptomics, it was possible to identify in the berry members of previously CW-related overlooked families such as pectin methylesterase inhibitors (PMEIs) or cellulose synthases (CesA) [114], as well as additional members of previously studied families associated with CW modifications. For instance, by using the Affymetrix Vitis GeneChip genome array, 10 members of the XTH family were modulated during development, four of them strongly up-regulated during ripening [113] compared to the two "candidate genes" previously investigated both in berry skin and flesh [87, 109]. Moreover, comprehensive comparisons of gene expression between pulp, skin and seed tissues are now facilitated [116].

Functional genomics of lignin biosynthesis is established for Arabidopsis with key genes identified by screening of mutant and transgenic plants, gene silencing, overexpression and other reverse-genetics approaches $[34,39,122]$. In the general lignin biosynthetic pathway, $\mathrm{C} 4 \mathrm{H}$, a cytochrome $\mathrm{P} 450$-dependent mono-oxygenase, converts cinnamic acid, the product of phenylalanine deamination, into $p$-coumaric acid, which is esterified with CoA to $p$-coumaroyl-CoA by 4CL. Then CCR, the first enzyme of the monolignol specific biosynthetic pathway converts the lateral chain of coumaroyl-CoA ester to its respective aldehyde. A further reduction step catalysed by CAD forms $p$-coumaryl alcohol - the monomer for $\mathrm{H}$ lignin. At $p$ coumaroyl- CoA level the pathway can give rise to a distinct branch: HCT converts $p$-coumaroyl-CoA to $p$ coumaroyl shikimic acid, which is converted to caffeoyl shikimic acid by $\mathrm{C} 3 \mathrm{H}$ (also a cytochrome $\mathrm{P} 450$ dependent mono-oxygenase), then converted to caffeoyl-CoA by HCT, which is methylated to feruoyl-CoA and finally converted to coniferyl aldehyde by CCR. From this metabolite two new branches can proceed: one catalysed by CAD giving rise to coniferyl alcohol, the monomer for G lignin; a second one with F5H, the third cytochrome P450-dependent mono-oxygenase of the pathway, catalysing the hydroxylation of coniferyl aldehyde to hydroxyconiferyl aldehyde, which is methylated to sinapyl aldehyde and finally dehydrogenated by CAD to sinapyl alcohol, the monomer for S lignin.

The expression of genes for most of the enzymes catalysing specific steps of lignin biosynthesis is suggested in the grape berry [114], although no experimental evidence is available at cellular or biochemical levels to support the above hypothesis. Furthermore, no reports are available on the crosslinks between lignin and polysaccharides in the grape seed secondary CW. In the grape berry pulp vascular tissue, immunogold labelling localised PAL to primary and secondary CW and 4CL to secondary thick walls [38]. The authors refer to a previous localisation of PAL to the cytoplasm and organelles, and C4H to the endoplasmic reticulum. The physiological significance of the compartmentalisation of phenylpropanoid pathway enzymes is therefore not totally clarified.

So far, only a few transcriptomic analyses of grape berry through Affymetrix Vitis GeneChip genome array refer the expression of genes for lignin biosynthesis enzymes. One transcript subset includes transcripts assigned to "phenolic acid" function. Quoting the NCBI GeneBank and Genoscope annotations, it was possible to establish the correspondence with specific genes coding for lignin biosynthesis enzymes (Table 3). The CCR and the first CAD listed express in ripening grapes eventually due to seed lignification at the maturation stage; whereas the second listed CAD, expressed in berries at the green stage, could be associated with xylem vasculature. 
Table 3: Correspondence between transcripts related to the grape berry "Phenolic acid metabolism" [114] pool, Unique Gene in Genoscope and ESTs and Proteins from NCBI GeneBank grape berry libraries.

\begin{tabular}{|l|l|l|l|l|}
\hline $\begin{array}{l}\text { Families of genes for } \\
\text { lignin biosynthesis }\end{array}$ & $\begin{array}{l}\text { GeneBank } \\
\text { annotation [114] }\end{array}$ & Genoscope unique gene & GeneBank EST & GeneBank protein \\
\hline CCR & CF517687 & GSVIVP00033763001 & $\begin{array}{l}\text { CF415449; } \\
\text { CABSAU36 }\end{array}$ & XP_002273454 \\
\hline CAD & CF512464 & GSVIVP00008719001 & $\begin{array}{l}\text { CV179328; } \\
\text { CABSAU36 }\end{array}$ & XP_002279832 \\
\hline CAD & CF517155 & GSVIVP00024587001 & BQ798918 & XP_002285368 \\
\hline
\end{tabular}

When grape berry mRNA expression profiles were analysed in the skin, pulp and seed tissues [123], two CCRs showed seed specific expression, one showed skin specific expression and two others were expressed in the pulp and skin or in the skin and seed. Four CAD isoforms showed preferential accumulation in the skin or in the skin and pulp, certainly in relation to vascular bundle formation. In a study oriented to identify genes specifically involved in berry ripening [113], transcripts associated with primary CW were mostly repressed before veraison and induced onwards, while a number of secondary metabolism genes were repressed BV but a higher number was induced PV. This category included genes of the phenylpropanoid pathway. The authors interpret the pattern of expression of one 4CL isoform, negatively modulated throughout the ripening process, as being involved in lignin biosynthesis, while a second 4CL isoform, positively modulated throughout the whole period of berry development and ripening, would be involved in the anthocyanin pathway.

\section{ABBREVIATIONS}

\begin{tabular}{|c|c|c|}
\hline $4 \mathrm{CL}$ & $=$ & 4-coumarate:CoA ligase \\
\hline AFase & $=$ & $\alpha$-L-arabinofuranosidase \\
\hline AGA & $=$ & Apiogalacturonan \\
\hline AG-I & $=$ & Arabinogalactan-I \\
\hline AG-II & $=$ & Arabinogalactan-II \\
\hline AGP & $=$ & Arabinogalactan protein \\
\hline BV & $=$ & Before veraison \\
\hline $\mathrm{C} 3 \mathrm{H}$ & $=$ & Coumarate 3-hydroxylase \\
\hline $\mathrm{C} 4 \mathrm{H}$ & $=$ & Cinnamate 4-hydroxylase \\
\hline CAD & $=$ & Cinnamyl alcohol dehydrogenase \\
\hline CCR & $=$ & Cinnamoyl-CoA reductase \\
\hline CesA & $=$ & Cellulose synthase \\
\hline $\mathrm{CW}$ & $=$ & Cell wall \\
\hline EGase & $=$ & $\beta$-1,4-endoglucanase \\
\hline
\end{tabular}




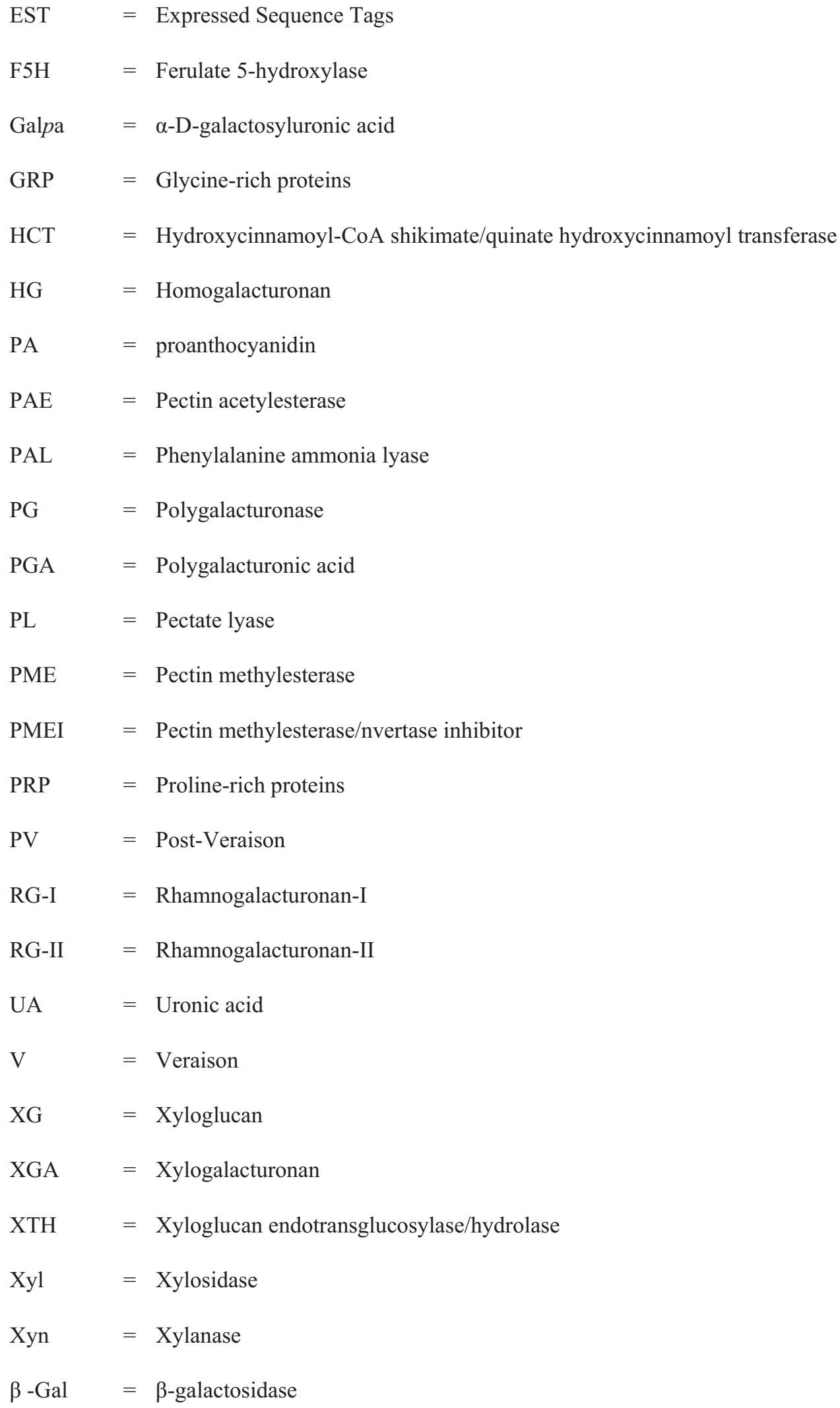




\section{ACKNOWLEDGEMENTS}

JCF and PL are awarded respectively the PhD grant SFRH/BD/64047/2009 and the annual grant for integration in research FCT/CBAA/BII-7-2009/2010. IICT is funded by MCTES and CBAA by the FCT "Plurianual" Programme.

\section{REFERENCES}

[1] Brett C, Waldron K. Physiology and Biochemistry of Plant Cell Walls. Chapman \& Hall, London 1996.

[2] Goulao LF, Almeida DPF, Oliveira CM. Effect of Enzymatic Reactions on Texture of Fruits and Vegetables. In: Bayindirli A, Ed. Enzymes in Fruit and Vegetable Processing: Chemistry and Engineering Applications. CRC Press (Taylor \& Francis), New York 2010; pp. 72-122.

[3] Pinelo M, Arnous A, Meyer AS. Upgrading of grape skins: Significance of plant cell-wall structural components and extraction techniques for phenol release. Trends Food Sci Technol 2006; 17(11): 579-90.

[4] Rapport L, Lockwood B. Nutraceuticals (6) Protoanthocyanidins and grape seed extract. Pharm J 2001; 17: 581-4.

[5] Bogs J, Jaffé F W, Takos AM, Walker AR, Robinson SP. The grapevine transcription factor VvMYBPA1 regulates proanthocyanidin synthesis during fruit development. Plant Physiol 2007; 143(3): 1347-61.

[6] Ortega-Regules A, Romero-Cascales I, Ros-García JM, López-Roca JM, Gómez-Plaza E. A first approach towards the relationship between grape skin cell-wall composition and anthocyanin extractability. Anal Chimica Acta 2006; 563(1-2): 26-32.

[7] Jaillon O, Aury J-M, Noel B, et al. The grapevine genome sequence suggests ancestral hexaploidization in major angiosperm phyla. Nature 2007; 449(7161): 463-7.

[8] Velasco R, Zharkikh A, Troggio M, et al. A high quality draft consensus sequence of the genome of a heterozygous grapevine variety. PLoS ONE 2007; 2(12): e1326.

[9] Carpita NC, Gibeaut DM. Structural models of primary cell walls in flowering plants: consistency of molecular structure with the physical properties of the walls during growth. Plant J 1993; 3(1): 1-30.

[10] McNeil M, Darvill AG, Fry SC, PA. Structure and function of the primary cell walls of plants. Annu Rev Biochem 1984; 53: 652-83.

[11] Hayashi T. Xyloglucans in the primary cell wall. Annu Rev Plant Physiol Plant Mol Biol 1989; 40(1): 139-68.

[12] Ordaz-Ortiz JJ, Marcus SE, Knox JP. Cell wall microstructure analysis implicates hemicellulose polysaccharides in cell adhesion in tomato fruit pericarp parenchyma. Mol Plant 2009; 2(5): 910-21.

[13] Voragen AGJ, Pilnik W, Thibault J-F, Axelos MAV, Renard CMGC. Pectins. In: Stephen AM, Ed. Food polysaccharides and their applications. Marcel Dekker, New York 1995; pp. 287-339.

[14] Thibault J-F, Renard CMGC, Axelos MAV, Roger P, Crépeau M-J. Studies of the length of homogalacturonic regions in pectins by acid hydrolysis. Carbohydrate Res 1993; 238: 271-86.

[15] Seymour GB, Colquhoun IJ, Dupont MS, Parsley KR, Selvendran R. Composition and structural features of cell wall polysaccharides from tomato fruits. Phytochemistry 1990; 29(3): 725-31.

[16] Muda P, Seymour GB, Errington N, Tucker GA. Compositional changes in cell wall polymers during mango fruit ripening. Carbohydrate Polym 1995; 26(4): 255-60.

[17] Liners F, Letesson JJ, Didembourg C, Van Cutsem P. Monoclonal antibodies against pectin: Recognition of a conformation induced by calcium. Plant Physiol 1989; 91(4): 1419-24.

[18] Goulao LF. Pectin de-esterification and fruit softening: revisiting a classical hypothesis. Stewart Postharvest Rev [Online] 2010; 6: 1-12.

[19] Albersheim P, Darvill AG, O’Neill MA, Schols HA, Voragen AGJ. In Pectins and pectinases, Visser J, Voragen AGJ, Eds. Elsevier Science B.V., Amsterdam, 1996; pp. 47-56.

[20] Caffall KH, Mohnen D. The structure, function, and biosynthesis of plant cell wall pectic polysaccharides. Carbohydrate Res 2009; 344(14): 1879-900.

[21] Voragen A, Coenen G-J, Verhoef R, Schols H. Pectin, a versatile polysaccharide present in plant cell walls. Struct Chem 2009; 20(2): 263-75.

[22] Kobayashi M, Nakagawa H, Asaka T, Matoh T. Borate-rhamnogalacturonan II bonding reinforced by Ca2+ retains pectic polysaccharides in higher-plant cell walls. Plant Physiol 1999; 119(1): 199-204.

[23] Ishii T, Matsunaga T, Pellerin P, O'Neill MA, Darvill A, Albersheim P. The plant cell wall polysaccharide rhamnogalacturonan II self-assembles into a covalently cross-linked dimer. J Biol Chem 1999; 274(19): 13098-104.

[24] O'Neill MA, Ishii T, Albersheim P, Darvill AG. Rhamnogalacturonan II: structure and function of a borate crosslinked cell wall pectic polysaccharide. Annu Rev Plant Biol 2004; 55: 109-39. 
[25] Ridley BL, O'Neill MA, Mohnen D. Pectins: structure, biosynthesis, and oligogalacturonide-related. signaling Phytochemistry 2001; 57(6): 929-67.

[26] Vincken J, Schols HA, Oomen RJ, et al. If homogalacturonan were a side chain of rhamnogalacturonan I. implications for cell wall architecture. Plant Physiol 2003; 132(4): 1781-9.

[27] Coenen GJ, Bakx EJ, Verhoef RP, Schols HA, Voragen AGJ. Identification of the connecting linkage between homoor xylogalacturonan and rhamnogalacturonan type I. Carbohydrate Polym 2007; 70(2): 224-35.

[28] O'Neill MA, York WS. The composition and structure of plant primary cell walls. In The Plant Cell Wall, Rose JKC, Ed. Blackwell Publishing, New York 2003; pp. 1-54.

[29] Showalter AM. Structure and function of plant cell wall proteins. Plant Cell 1993; 5(1): 9-23.

[30] Mort AJ, Lamport DTA. Anhydrous hydrogen-fluoride deglycosylates glycoproteins. Anal Biochem 1977; 82(2): 289-309.

[31] Majewska-Sawka A, Nothnagel EA. The multiple roles of arabinogalactan proteins in plant development. Plant Physiol 2000; 122(1): 3-10.

[32] Donaldson LA. Lignification and lignin topochemistry - an ultrastructural view. Phytochemistry 2001; 57(6): 859-73.

[33] Cadot Y, Miñana-Castelló MT, Chevalier M. Anatomical, histological, and histochemical changes in grape seeds from Vitis vinifera L. cv Cabernet franc during fruit development. J Agric Food Chem 2006; 54(24): 9206-15.

[34] Bonawitz ND, Chapple C. The genetics of lignin biosynthesis: connecting genotype to phenotype. Annu Rev Genet 2010; 44: 337-63.

[35] Boerjan W, Ralph J, Baucher M. Lignin biosynthesis. Annu Rev Plant Biol 2003; 54: 519-46.

[36] Vanholme R, Morreel K, Ralph J, Boerjan W. Lignin engineering. Curr Op Plant Biol 2008; 11(3): 278-85.

[37] Vanholme R, Demedts B, Morreel K, Ralph J, Boerjan W. Lignin biosynthesis and structure. Plant Physiol 2010; 153(3): 895-905.

[38] Chen J-Y, Wen P-F, Kong W-F, Pan Q-H, Wan S-B, Huang W-D. Changes and subcellular localizations of the enzymes involved in phenylpropanoid metabolism during grape berry development. J Plant Physiol 2006; 163(2): $115-27$.

[39] Goujon T, Sibout R, Eudes A, MacKay J, Jouanin L. Genes involved in the biosynthesis of lignin precursors in Arabidopsis thaliana. Plant Physiol Biochem 2003; 41(8): 677-87.

[40] Stewart JJ, Akiyama T, Chapple C, Ralph J, Mansfield SD. The effects on lignin structure of overexpression of ferulate 5-hydroxylase in hybrid poplar. Plant Physiol 2009; 150(2): 621-35.

[41] Fry SC. The structure and functions of xyloglucan. J Exp Bot 1989; 40: 1-11.

[42] Bootten TJ, Harris PJ, Melton LD, Newman RH. Solid-state ${ }^{13} \mathrm{C}-\mathrm{NMR}$ spectroscopy shows that the xyloglucans in the primary cell walls of mung bean (Vigna radiata L.) occur in different domains: a new model for xyloglucancellulose interactions in the cell wall. J Exp Bot 2004; 55: 571-83.

[43] Hanus J, Mazeau K. The xyloglucan-cellulose assembly at the atomic scale. Biopolymers 2006; 82(1): 59-73.

[44] Bootten TJ, Harris PJ, Melton LD, Newman RH. Solid-state ${ }^{13} \mathrm{C}$ NMR study of a composite of tobacco xyloglucan and Gluconacetobacter xylinus cellulose: molecular interactions between the component polysaccharides. Biomacromolec 2009; 10(11): 2961-7.

[45] Cosgrove DJ. Wall structure and wall loosening. A look backwards and forwards. Plant Physiol 2001; 125(1): 131-4.

[46] Oechslin R, Lutz MV, Amadò R. Pectic substances isolated from apple cellulosic residue: structural characterisation of a new type of rhamnogalacturonan I. Carbohydrate Polym 2003; 51(3): 301-10.

[47] Vignon MR, Heux L, Malainine ME, Mahrouz M. Arabinan-cellulose composite in Opuntia ficus-indica prickly pear spines. Carbohydrate Res 2004; 339(1): 123-31.

[48] Zykwinska AW, Ralet MCJ, Garnier CD, Thibault JFJ. Evidence for in vitro binding of pectin side chains to cellulose. Plant Physiol 2005; 139(1): 397-407.

[49] Zykwinska A, Rondeau-Mouro C, Garnier C, Thibault J-F, Ralet M-C. Alkaline extractability of pectic arabinan and galactan and their mobility in sugar beet and potato cell walls. Carbohydrate Polym 2006; 65(4): 510-20.

[50] Zykwinska A, Gaillard C, Buléon A, Pontoire B, Garnier C, Thibault J-F, Ralet M-C. Assessment of in vitro binding of isolated pectic domains to cellulose by adsorption isotherms, electron microscopy, and X-ray diffraction methods. Biomacromolec 2006; 8(1): 223-32.

[51] Zykwinska A, Thibault JF, Ralet MC. Organization of pectic arabinan and galactan side chains in association with cellulose microfibrils in primary cell walls and related models envisaged. J Exp Bot 2007; 58: 1795-802.

[52] Femenia A, Rigby NM, Selvendran RR, Waldron KW. Investigation of the occurrence of pectic-xylan-xyloglucan complexes in the cell walls of cauliflower stem tissues. Carbohydrate Polym 1999; 39(2): 151-64. 
[53] Abdel-Massih R, Baydoun E, Brett C. In vitro biosynthesis of 1,4-ß-galactan attached to a pectin-xyloglucan complex in pea. Planta 2003; 216(3): 502-11.

[54] Cumming C, Rizkallah H, McKendrick K, Abdel-Massih R, Baydoun E, Brett C. Biosynthesis and cell-wall deposition of a pectin-xyloglucan complex in pea. Planta 2005; 222(3): 546-55.

[55] Popper ZA, Fry SC. Widespread occurrence of a covalent linkage between xyloglucan and acidic polysaccharides in suspension-cultured angiosperm cells. Ann Bot 2005; 96(1): 91-9.

[56] Popper Z, Fry S. Xyloglucan-pectin linkages are formed intra-protoplasmically, contribute to wall-assembly, and remain stable in the cell wall. Planta 2008; 227(4): 781-94.

[57] Marcus SE, Verhertbruggen Y, Hervé C, et al. Pectic homogalacturonan masks abundant sets of xyloglucan epitopes in plant cell walls. BMC Plant Biol 2008; 8: 60.

[58] Vissenberg K, Martinez-Vilchez IM, Verbelen JP, Miller JG, Fry SC. In vivo colocalization of xyloglucan endotransglycosylase activity and its donor substrate in the elongationzone of Arabidopsis roots. Plant Cell 2000; 12(7): 1229-38.

[59] McCartney L, Steele-King CG, Jordan E, Knox JP. Cell wall pectic $(1 \rightarrow 4)-\beta$-D-galactan marks the acceleration of cell elongation in the Arabidopsis seedling root meristem. Plant J 2003; 33(3): 447-54.

[60] Ha M-A, Viëtor RJ, Jardine GD, Apperley D C, Jarvis MC. Conformation and mobility of the arabinan and galactan side-chains of pectin. Phytochemistry 2005; 66(15): 1817-24.

[61] Jarvis MC. Plant cell walls: Supramolecular assemblies. Food Hydrocol 2011; 25(2): 257-62.

[62] Gorshkova T, Mikshina P, Gurjanov O, Chemikosova S. Formation of plant cell wall supramolecular structure. Biochemistry (Moscow) 2010; 75(2): 159-72.

[63] Scheller HV, Ulvskov P. Hemicelluloses. Annu Rev Plant Biol 2010; 61: 263-89.

[64] Nunan KJ, Sims IM, Bacic A, Robinson SP, Fincher GB. Isolation and characterization of cell walls from the mesocarp of mature grape berries (Vitis vinifera). Planta 1997; 203(1): 93-100.

[65] Vidal S, Williams P, O'Neill MA, Pellerin P. Polysaccharides from grape berry cell walls. Part I: tissue distribution and structural characterization of the pectic polysaccharides. Carbohydrate Polym 2001; 45(4): 315-23.

[66] Hardie WJ, O'Brien TP, Jaudzems VG. Morphology, anatomy and development of the pericarp after anthesis in grape, Vitis vinifera L. Aust J Grape Wine Res 1996; 2(2): 97-142.

[67] Lecas M, Brillouet J-M. Cell wall composition of grape berry skins. Phytochemistry 1994; 35(5): 1241-3.

[68] Saulnier L, Thibault J-F. Enzymic degradation of isolated pectic substances and cell wall from pulp of grape berries. Carbohydrate Polym 1987; 7(5): 345-60.

[69] Bindon KA, Smith PA, Holt H, Kennedy JA. Interaction between grape-derived proanthocyanidins and cell wall material. 2. Implications for vinification J Agri Food Chem 2010; 58(19): 10736-46.

[70] Hilz H. Characterisation of cell wall polysaccharides in bilberries and black currants. PhD Thesis, U. Wageningeng: Wageningen, NL, 2007; p. 158.

[71] Doco T, Williams P, Pauly M, O'Neill MA, Pellerin P. Polysaccharides from grape berry cell walls. Part II. Structural characterization of the xyloglucan polysaccharides. Carbohydrate Polym 2003; 53(3): 253-261.

[72] Arnous A, Meyer A. Grape skins (Vitis vinifera L.) catalyze the in vitro enzymatic hydroxylation of $p$-coumaric acid to caffeic acid. Biotech Lett 2009; 31(12): 1953-60.

[73] Fry SC, York WS, Albersheim P, et al. An unambiguous nomenclature for xyloglucan-derived oligosaccharides. Physiol Plant 1993; 89(1): 1-3.

[74] Nunan KJ, Sims IM, Bacic A, Robinson SP, Fincher GB. Changes in cell wall composition during ripening of grape berries. Plant Physiol 1998; 118(3): 783-92.

[75] Gross KC, Sams CE. Changes in cell wall neutral sugar composition during fruit ripening: a species survey. Phytochemistry 1984; 23(11): 2457-61.

[76] Brummell DA. Cell wall disassembly in ripening fruit. Funct Plant Biol 2006; 33: 103-19.

[77] Goulao LF, Oliveira CM. Cell wall modifications during fruit ripening: when a fruit is not the fruit. Trends Food Sci Technol 2008; 19(1): 4-25.

[78] Zhang DP, Li M, Wang Y. Ultrastructural changes in the mesocarp cells of grape berry during its development. Acta Botanica Sinica 1997; 39: 389-96.

[79] Liners F, Van Cutsem P. Distribution of pectic polysaccharides throughout walls of suspension-cultured carrot cells. Protoplasma 1992; 170(1): 10-21.

[80] Fougère-Rifot M, Cholet C, Bouard J. Evolution des parois des cellules de l'hypoderme de la baie de raisin lors de leur transformation en cellules de pulpe. J Int Sci Vigne Vin 1996; 30: 47-51. 
[81] Barnavon L, Doco T, Terrier N, Ageorges A, Romieu C, Pellerin P. Involvement of pectin methyl-esterase during the ripening of grape berries: partial cDNA isolation, transcript expression and changes in the degree of methylesterification of cell wall pectins. Phytochemistry 2001; 58(5): 693-701.

[82] Barnavon L, Doco T, Terrier N, Ageorges A, Romieu C, Pellerin P. Analysis of cell wall neutral sugar composition, beta-galactosidase activity and a related cDNA clone throughout the development of Vitis vinifera grape berries. Plant Physiol Biochem 2000; 38: 289-300.

[83] Ortega-Regules A, Ros-García JM, Bautista-Ortín AB, López-Roca JM, Gómez-Plaza E. Changes in skin cell wall composition during the maturation of four premium wine grape varieties. J Sci Food Agric 2008; 88: 420-8.

[84] Silacci MC, Morrison JC. Changes in pectin content of Cabernet Saubignon grape berries during maturation. Am J Enol Vitic 1990; 41: 111-5.

[85] Yakushiji H, Sakurai N, Morinaga K. Changes in cell-wall polysaccharides from the mesocarp of grape berries during veraison. Physiol Plantarum 2001; 111(2): 188-95.

[86] Grignon C, Sentenac H. pH and ionic conditions in the apoplast. Annu Rev Plant Physiol Plant Mol Biol 1991; 42: $103-28$.

[87] Nunan K, Davies C, Robinson S, Fincher G. Expression patterns of cell wall-modifying enzymes during grape berry development. Planta 2001; 214(2): 257-64.

[88] Huang X-M, Huang H-B, Wang H-C. Cell walls of loosening skin in post-veraison grape berries lose structural polysaccharides and calcium while accumulate structural proteins. Sci Hortic 2005; 104(3): 249-63.

[89] Vicens A, Fournand D, Williams P, Sidhoum L, Moutounet M, Doco T. Changes in polysaccharide and protein composition of cell walls in grape berry skin (cv. Shiraz) during ripening and over-ripening J Agric Food Chem 2009; 57(7): 2955-60.

[90] Matthews MA, Cheng G, Weinbaum SA. Changes in water potential and dermal extensibility during grape berry development. J Am Soc Hortic Sci 1987; 112: 314-9.

[91] Huang X-M, Huang H-B. Early post-veraison growth in grapes: evidence for a two-step mode of berry enlargement. Aust J Grape Wine Res 2001; 7(3): 132-6.

[92] Schlosser J, Olsson N, Weis M, et al. Cellular expansion and gene expression in the developing grape (Vitis vinifera L.). Protoplasma 2008; 232(3): 255-65.

[93] Bondada BR, Matthews MA, Shackel KA. Functional xylem in the post-veraison grape berry. J Exp Bot 2005; 56(421): 2949-57.

[94] Morales M, Pedreño MA, Muñoz R, Barceló AR, Calderón AA. Purification and kinetic characterization of a basic peroxidase isoenzyme responsible for lignification in Gamay rouge grape (Vitis vinifera) berries. Food Chem 1993; 48(4): 391-4.

[95] Moldes D, Gallego PP, Rodríguez Couto S, Sanromán A. Grape seeds: the best lignocellulosic waste to produce laccase by solid state cultures of Trametes hirsuta. Biotechnol Lett 2003; 25(6): 491-5.

[96] Ristic R, Iland PG. Relationships between seed and berry development of Vitis Vinifera L. cv Shiraz: Developmental changes in seed morphology and phenolic composition. Aust J Grape Wine Res 2005; 11(1): 43-58.

[97] Hanlin RL, Hrmova M, Harbertson JF, Downey MO. Condensed tannin and grape cell wall interactions and their impact on tannin extractability into wine. Aust J Grape Wine Res 2010; 16(1): 173-88.

[98] Kennedy J. Understanding grape berry development. Practical Winery and Vineyard [Online], 2002.

[99] Kennedy JA, Hayasaka Y, Vidal S, Waters EJ, Jones GP. Composition of grape skin proanthocyanidins at different stages of berry development. J Agric Food Chem 2001; 49(11): 5348-55.

[100] Río Segade S, Rolle L, Gerbi V, Orriols I. Phenolic ripeness assessment of grape skin by texture analysis. J Food Compos Anal 2008; 21(8): 644-9.

[101] Fischer RL, Bennett AB. Role of cell-wall hydrolases in fruit ripening. Annu Rev Plant Physiol Plant Mol Biol 1991; 42: 675-703.

[102] Hadfield KA, Bennett AB. Polygalacturonases: many genes in search of a function. Plant Physiol 1998; 117(2): 33743.

[103] Seymour GB, Gross KC. Cell wall disassembly and fruit softening. Postharvest News and Information 1996; 7: 45N$52 \mathrm{~N}$.

[104] Hayashi T, Takeda T, Ogawa K, Mitsuishi Y. Effects of the degree of polymerization on the binding of xyloglucans to cellulose. Plant Cell Physiol 1994; 35(6): 893-9.

[105] Mitcham EJ, Gross KC, Ng TJ. Tomato fruit cell wall synthesis during development and senescence 1: In vivo radiolabeling of wall fractions using [14C] sucrose. Plant Physiol 1989; 89(2): 477-81. 
[106] Greve LC, Labavitch JM. Cell wall metabolism in ripening fruit 1: V. Analysis of cell wall synthesis in ripening tomato pericarp tissue using a d-[U-13C]glucose tracer and gas chromatography-mass spectrometry. Plant Physiol 1991; 97(4): 1456-61.

[107] Jansson S, Douglas CJ. Populus: a model system for plant biology. Annu Rev Plant Biol 2007; 58: 435-58.

[108] Page RD. TreeView: an application to display phylogenetic trees on personal computers. Comput Appl Biosci 1996; 12(4): 357-8.

[109] Ishimaru M, Kobayashi S. Expression of a xyloglucan endo-transglycosylase gene is closely related to grape berry softening. Plant Sci 2002; 162(4): 621-8.

[110] Ishimaru M, Smith DL, Gross KC, Kobayashi S. Expression of three expansin genes during development and maturation of Kyoho grape berries. J Plant Physiol 2007; 164(12): 1675-82.

[111] Goulao LF, Santos J, de Sousa I, Oliveira CM. Patterns of enzymatic activity of cell wall-modifying enzymes during growth and ripening of apples. Postharvest Biol Technol 2007; 43(3): 307-18.

[112] Goulao LF, Cosgrove DJ, Oliveira CM. Cloning, characterisation and expression analyses of cDNA clones encoding cell wall-modifying enzymes isolated from ripe apples. Postharvest Biol Technol 2008; 48(1): 37-51.

[113] Pilati S, Perazzolli M, Malossini A, et al. Genome-wide transcriptional analysis of grapevine berry ripening reveals a set of genes similarly modulated during three seasons and the occurrence of an oxidative burst at vèraison. BMC Genom 2007; 8: 428.

[114] Deluc LG, Grimplet J, Wheatley MD, et al. Transcriptomic and metabolite analyses of Cabernet Sauvignon grape berry development. BMC Genom 2007; 8: 429.

[115] Chervin C, Tira-umphon A, Terrier N, Zouine M, Severac D, Roustan J-P. Stimulation of the grape berry expansion by ethylene and effects on related gene transcripts, over the ripening phase. Physiol Plantarum 2008; 134(3): 534-46.

[116] Grimplet J, Deluc L, Tillett R, et al. Tissue-specific mRNA expression profiling in grape berry tissues. BMC Genom 2007; 8(1): 187.

[117] Terrier N, Glissant D, Grimplet J, et al. Isogene specific oligo arrays reveal multifaceted changes in gene expression during grape berry (Vitis vinifera L.) development. Planta 2005; 222(5): 832-47.

[118] Silva F, Iandolino A, Al-Kayal F, et al. Characterizing the grape transcriptome. Analysis of Expressed Sequence Tags from multiple Vitis species and development of a compendium of gene expression during berry development. Plant Physiol 2005; 139(2): 574-97.

[119] Terrier N, Ageorges A, Abbal P, Romieu C. Generation of ESTs from grape berry at various developmental stages. J Plant Physiol 2001; 158(12): 1575-83.

[120] Koyama K, Sadamatsu K, Goto-Yamamoto N. Abscisic acid stimulatedripening and gene expression in berry skins of the Cabernet Sauvignon grape. Funct Integr Genom 2010; 10(3): 367-281.

[121] Peng FY, Reid KE, Liao N, et al. Generation of ESTs in Vitis vinifera wine grape (Cabernet Sauvignon) and table grape (Muscat Hamburg) and discovery of new candidate genes with potential roles in berry development. Gene 2007; 402(1-2): 40-50.

[122] Raes J, Rohde A, Christensen JH, Van de Peer Y, Boerjan W. Genome-wide characterization of the lignification toolbox in Arabidopsis. Plant Physiol 2003; 133(3): 1051-71.

[123] Deluc L, Barrieu F, Marchive C, et al. Characterization of a grapevine R2R3-MYB transcription factor that regulates the phenylpropanoid pathway. Plant Physiol 2006; 140(2): 499-511. 